\title{
HR-outsourcing in Natural resources sector
}

\author{
Elena Ganebnykh ${ }^{1, *}$, Larisa Kozlova ${ }^{2}$, and Eאaterina Stativa ${ }^{3}$ \\ ${ }^{1}$ Vyatka State University, Moskovskaya str., 36, Kirov, 610000, Russia \\ ${ }^{2}$ Vyatka State Agrotechnological University, Oktyabrsky avenue, 133, Kirov, 610017, Russia \\ ${ }^{3}$ Moscow State University of Civil Engineering, 26 Yaroslavskoye Shosse, Moscow, 129377, Russia
}

\begin{abstract}
The article analyzes HR outsourcing market in the Natural resource sector. This industry is profitable, but it is characterized by a lack of staff due to the educational drop of the 1990s - 2000s and the number of young specialists in this sector has not still been restored. The rapid technological development of the Natural resource sector requires constant training of staff, which is hampered by many factors: long operating cycles of deposits without changing technologies, natural outflow of experienced employees due to aging, remoteness of locations, and a pandemic. The research underlines that today recruitment agencies are not able to satisfy the search and selection service for the Natural resource sector. The observed general trend of HR outsourcing towards process management and personnel training is relevant in the Natural resource sector even more than in other industries, especially in the area of personnel training. Thus, there is a certain process of transformation of the education system in this industry. It requires new models of training young personnel and retraining the existing personnel, probably using lifetime learning technologies.
\end{abstract}

\section{Introduction}

Human resources play a key role in the sustainable development of the economy, including the Natural resources sector. The existing problem with the educational training of young specialists for this industry [1] is partly solved by additional education, which has been gaining popularity in recent years, that is, specialized highly specialized courses. Online education opportunities have also forced industry companies to pay attention to staff qualifications even during the pandemic.

Another staff problem in the Natural resources sector is using a high number of foreign specialists in comparison with other sectors of the Russian economy. More foreign employees are attracted only by Hight-tech and IT industries [2], while these industries often work remotely. The Natural Resources industry requires face-to-face presence, but the pandemic period has led to the closure of borders and an increase in the demand for specialists within the country.

The Fuels and Energy Technology Development Institute (IRTTEK) states that $89.3 \%$ of companies in the industry experience a shortage of personnel [3].

The XIV All-Russian Conference of HR Managers held in March 2015, Moscow was attended by HR directors of the country's leading oil and gas companies: Gazprom Neft,

\footnotetext{
*Corresponding author: ganebnykh@mail.ru
} 
Rosneft, TNK-BP Management, Slavneft, Lukoil Oversize Services, Tatneft, Integra Management, as well as representatives of government agencies: the federal migration service of Russia, the federal service for labor and employment, pension funds and trade unions. Most of the conference participants noted the following negative trends in the industry:

- low level of intellectual, technical and managerial potential;

- insufficient elaboration of modern standards of managerial and professional competencies for employees of the oil and gas industry;

- closedness of oil and gas enterprises for professionals from other sectors of the national economy $[4,5]$.

There are many specialists in Russia who want to work in the Natural resource sector, but not all applicants are able to meet the requirements of companies. Head Hunter, analyzing the wishes of job seekers, points out that $48 \%$ of respondents would prefer to get a job in the oil and gas industry. But at the same time, the real state of affairs on the labor market in this sector suggests that even the largest companies, which have serious resources to hire new employees, have a lack of personnel. What is the reason for the "staff shortage"?

The Natural resource sector has a number of specific features that affect personnel. First, in the mining sector, the development and operation cycle of a deposit is 25-30 years [6]. The next cycle will be more technological, with a 25 -year gap, that is, the technology gap will be huge. Employees who have worked for a quarter of a century using the same technology are not able to make a qualitative jump at once, it takes time for retraining. Most often, these are people over 50 years old, and they, in general, are not able to learn new technologies or do not want to do it.

Secondly, scientific and technological progress in the Natural resources sector is moving so rapidly that teachers of educational institutions cannot cope with changes. Graduates often finish the university and come to a company with outdated knowledge. The issue can be resolved only in the lifetime learning format, and it requires completely new approaches to the training system in this sector.

In this regard, there are burning questions about the need for changes in the personnel work of enterprises in the Natural resources sector. Today, human resources management has become one of the strategic priorities of companies operating in the Natural resources sector, which has led to the active development of recruitment in the market. These companies in Russia are paying more and more attention to HR departments responsible for personnel management. They have also began to use the services of recruiting agencies to resolve personnel issues.

An analysis of the HR recruitment market showed that in 2019, 24\% of all permanent vacancies were in the oil and gas and energy sectors. This trend repeated itself in 2020.

Modern trends in the development of HR outsourcing show that recruiting agencies are expanding their activities, moving away from hiring personnel and HR administration in two directions: process management and personnel training. This is largely facilitated by the availability of digital recruiting tools in the mass market. However, it affects the Natural resources sector to a lesser extent than other industries due to the above-mentioned circumstances related to the specifics of education.

The research is devoted to the analysis of the Russian HR outsourcing market. It helps understand how it fits with the needs of the industry, and also indicates empty or underfilled niches. 


\section{Methods and Materials}

The analysis of the Russian HR outsourcing market was carried out by a desk method, information was taken from open sources. Based on the classifier of types of economic activities, the total number of recruiting agencies in the country is slightly less than 5 thousand. The general population of the study is 1018 market participants $(100 \%$ of recruitment agencies in Moscow).

On the market there are:

- International HR-companies with a representative office in Moscow,

- Russian HR-companies of federal scale,

- Regional HR companies without branches and representative offices in other regions,

- Local highly specialized recruiting agencies.

There are not so many truly largest international companies with big names in Russia (Table 1).

Table 1. International HR-companies.

\begin{tabular}{|c|c|c|c|}
\hline № & Name & Website & Description \\
\hline 1 & Ancor & https://ancor.ru & $\begin{array}{l}\text { Has more than } 40 \text { offices in } 5 \\
\text { countries of the world and more than } \\
1,500 \text { permanent client companies. } \\
\text { The recruiting agency has } 4 \text { main } \\
\text { areas of activity: outsourcing, } \\
\text { recruitment, staffing, consulting. }\end{array}$ \\
\hline 2 & Staffline & https://staffline.ru & $\begin{array}{l}\text { Executive search, regional selection, } \\
\text { search for rare professions. } \\
\text { Consulting in the field of office } \\
\text { work, document management, } \\
\text { personnel management, creating } \\
\text { business plans }\end{array}$ \\
\hline 3 & Hays & https://hays.ru & $\begin{array}{l}252 \text { offices located in } 33 \text { countries. } \\
\text { OPC- outplacing (support and } \\
\text { professional advice of dismissed } \\
\text { employees), in demand by large } \\
\text { client companies when reducing or } \\
\text { reorganizing staff }\end{array}$ \\
\hline 4 & Kelly Services & https://www.kellyservices.ru/ & $\begin{array}{l}\text { Covers more than } 40 \text { countries, } 22 \\
\text { offices in Russia. Specializes in the } \\
\text { search and selection of personnel, } \\
\text { has been working with job seekers } \\
\text { for a very long time - maintaining a } \\
\text { career path }\end{array}$ \\
\hline 5 & Antal & $\begin{array}{l}\text { https://www.antal.com } \\
\text { https://antalrussia.ru/about/ }\end{array}$ & $\begin{array}{l}145 \text { offices around the world. } \\
\text { Specializes in the selection of } \\
\text { personnel for middle and top } \\
\text { management } \\
\text { Recruitment for the oil and gas and } \\
\text { mining sector }\end{array}$ \\
\hline 6 & Brunel Russia & $\begin{array}{l}\text { https://www.brunel.net/en/ } \\
\text { europe/russia }\end{array}$ & \\
\hline 7 & $\begin{array}{l}\text { Coleman } \\
\text { Services }\end{array}$ & https://www.coleman.ru/ & $\begin{array}{l}\text { Search and selection of personnel, } \\
\text { outstaffing, consulting, outsourcing }\end{array}$ \\
\hline 8 & ManpowerGroup & https://manpowergroup.ru/ & $\begin{array}{l}3100 \text { offices located in } 80 \text { countries } \\
\text { of the world. Recruitment and }\end{array}$ \\
\hline
\end{tabular}




\begin{tabular}{|l|l|l|}
\hline & & $\begin{array}{l}\text { selection of jobs in international } \\
\text { companies, labor protection, } \\
\text { consulting }\end{array}$ \\
\hline
\end{tabular}

All companies have a wide geographic presence with a large number of offices in different countries. Traditionally, their clients are the largest international companies, pulling an HR agency to each new location. The main service of all agencies is the search and selection of personnel, but each has its own specialization.

To understand the problems of enterprises in the Natural resource sector, a number of in-depth interviews were conducted with heads of HR services or specialists from these departments. In total, 3 in-depth interviews were conducted with representatives of the companies JSC "Vorkutaugol", JSC "National Non-Metallic Company" and the "Nobel Oil" holding. The characteristics of the respondents are shown in Table 2.

Table 2. Characteristics of respondents.

\begin{tabular}{|c|l|c|c|}
\hline \multirow{2}{*}{ № } & \multicolumn{1}{|c|}{ Name } & $\begin{array}{c}\text { Average } \\
\text { revenue, } \\
\mathbf{2 0 1 9}\end{array}$ & $\begin{array}{c}\text { Revenue } \\
\mathbf{2 0 1 9 ,} \\
\text { million rubles }\end{array}$ \\
\hline 1 & JSC "Vorkutaugol" & 15000 & 34301.0 \\
\hline 2 & JSC "National Non-Metallic Company" & 1658 & 22089.5 \\
\hline 3 & Holding "Nobel Oil" & 7500 & 42030.8 \\
\hline
\end{tabular}

\section{Results}

In total, in January 2021, the market had 20,285 vacancies in the Natural resource sector, 2,142 were in Moscow, 1139 - in St. Petersburg and 19047 in the regions of Russia. For half of the vacancies, the income level was indicated, and in $100 \%$ of cases it exceeded the national average, and in half of the cases it was twice or higher than the national average. $47 \%$ of vacancies required 1 to 3 years of work experience, which indicated the willingness of companies to train young specialists. Almost all vacancies offered full-time employment, however, the work schedule is different (Fig. 1).

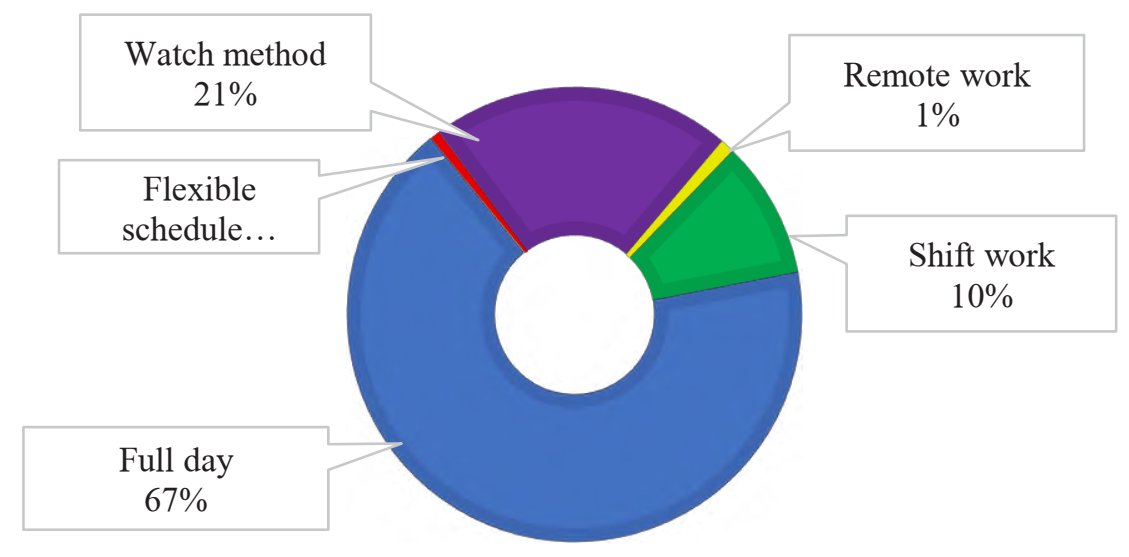

Fig. 1. Schedule of the offered vacancies.

Analysis of vacancies on the Internet indicates uneven volumes of work in terms of recruitment among international companies (Fig. 2). 


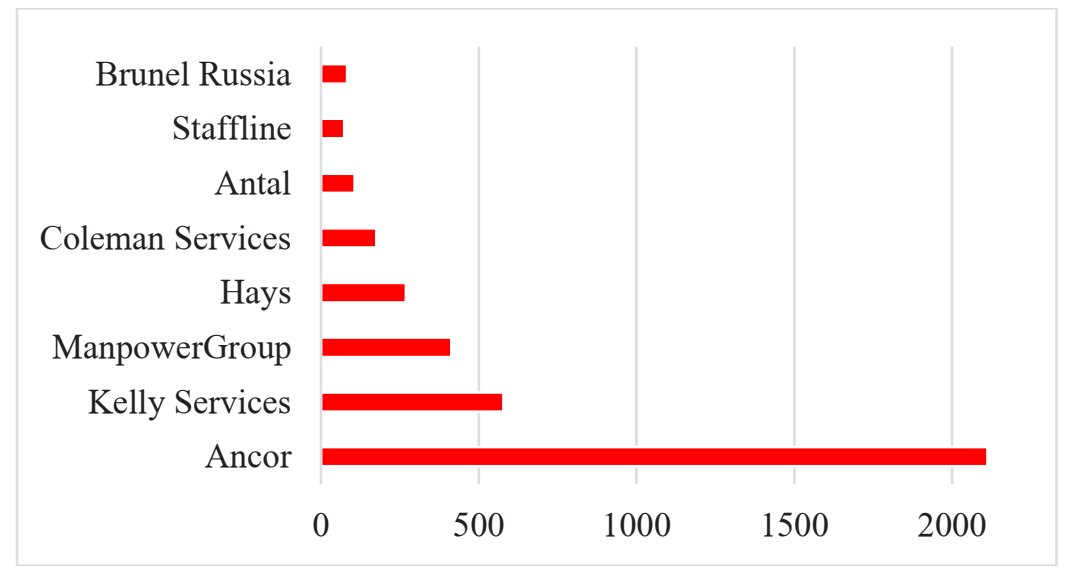

Fig. 2. Number of vacancies for international recruiting agencies.

Analysis of job sites has shown that international agencies do not always have a wide range of vacancies. The study has identified 44 companies that are most active in the personnel market (more than 20 vacancies). The obvious leader by a wide margin is the international company Ancor (2,148 vacancies), otherwise there is no direct relationship between the number of vacancies and the origin of the company. Only half of international companies are represented by a large number of vacancies. Market leaders - KS International, Kelly Services, ManpowerGroup, Unity, VENTRA and The Right Choice (> 200 vacancies) - have almost no specializations and cover the largest possible range of HR services for their clients.

In-depth interviews have made it possible to assess the current situation of enterprises in the Natural resource sector and evaluate prospects for personnel outsourcing.

JSC "Vorkutaugol" maintains a staff of HR specialists (12 people), but since the enterprise is a part of the "Severstal" holding, many functions for personnel management and development are centralized. However, personnel administration, search and selection of personnel, certification, training, motivation and incentives are delegated to places. Moreover, each mine has its own personnel accounting specialists (often part-time employees with accounting functions - tabulation, time tracking).

The company often practices hiring personnel for temporary vacancies. Since wages in these enterprises are higher than the regional average, workers are willingly hired, and the enterprise has the ability to screen out unsuitable candidates without unnecessary legal barriers. Thus, temporary contracts are not a compulsory measure due to the specifics of the work, but rather a way to dismiss unnecessary workers without conflict. At the same time, the probationary period, according to the head of the HR department, in most cases is just a formality. "If an employee does not suit us (most often it is alcohol abuse or conflict behavior, fights), then we will always find a way to fire him." The company has its own security service, which checks all candidates and takes away workers who have already proven themselves to be unreliable.

The enterprise recognizes that there is a huge gap between the administrative and production staff. Self-assessment has shown that the administrative staff knows well the mission and strategy of the company, has a high culture of organization and interaction. At the same time, interpersonal conflicts that arise in the places of residence of temporary workers are not uncommon among personnel. The reason for the emergence of conflicts, in their opinion, is that the team is constantly changing, people do not have time to "get used to" each other, there is a constant struggle for authority. The rules of the employment 
contract clearly indicate the inadmissibility of such conflicts, therefore, after the first warning, they fire the conflicting employee.

The personnel qualification problem is solved through a well-developed internal training system. The structure of the enterprise has its own training center, where periodic qualifications assessment, certification of personnel and advanced training courses take place, including those with certification from the National Welding Control Agency. The central office of the "Severstal" holding organizes refresher courses, trainings and seminars for engineering and technical and administrative personnel. The company also cooperates with educational institutions of secondary specialized and higher education, organizes practice and employs graduates. JSC "Vorkutaugol" has a program of professional internships with wages, although this tool is more popular in the horizontal rotation of personnel.

JSC "Vorkutaugol" has a successful experience of cooperation with recruiting agencies that attract temporary personnel from different regions. There has been no deeper interaction yet.

At the National Non-Metallic Company JSC (NNC JSC), mining open pits are merged with the simultaneous closure of two old, exhausted, but significant deposits in the past. Therefore, the company is undergoing changes related to relocation, building a structure at new production sites, hiring personnel. At the same time, JSC "NNC" notes the stability of the administrative staff. Employees of mining pits work, as a rule, on temporary contracts, often on a rotational basis. This is a deliberate move by the company, and this kind of staff rotation is not considered to be a "turnover". The staff of engineering and technical personnel and highly qualified specialists is stable, the company pays much attention to developing their skills and maintaining a high level of loyalty. According to selfassessment, the company considers its team to be close-knit, however, informal relationships require personal acquaintances, and remote employees do not know each other.

The search and selection of personnel mainly occurs through job sites (they post their own vacancies, and also look through the resume). The company does not practice searching for new employees through word of mouth, since "the required qualifications are so specific that it is useless to wait for a candidate from this channel". JSC "NNC" has experience in personnel outsourcing in terms of recruitment, but this experience was onetime in management positions, so it did not go into regular practice.

NNC JSC uses a probationary period when hiring personnel, but in most cases, this is a formality. The company has its own security service, which carefully checks candidates, but in general, candidates undergo a probationary period in the vast majority of cases. Dismissals of employees on the initiative of NNC JSC are extremely rare cases, and in such cases the employer always finds consensus with the dismissed.

Personnel development in terms of training is carried out systematically within the company, the involvement of third-party specialists is extremely rare, and is mainly used for top management.

Nobel Oil is going through difficult times now, as in the summer of 2020, the CEO of the holding was arrested on charges of embezzling financial assets. At the same time, an attempt was made to replace one of the key Chinese investors in the holding, which also negatively affected the company's assets. Now the assets of the company have been arrested, but the activities are ongoing, there are no suspensions. The processes of working with personnel are at the moment reduced to the obligatory minimum, therefore, no one is engaged in broadcasting ideas about the development strategy, and in general, the mission is remembered only in the higher administrative apparatus.

The structure of the Nobel Oil holding includes a number of companies that have their own HR services. The central office of the holding consists of only 300 people; this 
personnel is managed by 2 employees. The respondent found it difficult to estimate the total number of HR specialists in all enterprises of the holding.

According to self-assessment, the company considers its team to be rather cohesive and conflict-free. At the same time, if an arising problem is solved on the spot by the direct manager, then the company does not consider the situation to be problematic at all. "Problems are when the inspection authorities come on the complaint of an employee. Then the lawyer deals with it", the respondent commented.

Nobel Oil has a special adaptation program for employees, but it is limited only to mentoring: each new employee is assigned a mentor for a period of 3 months (probationary period), then the employee is assessed, and a decision is made on the need to extend the mentoring. This is individual and depends on the specifics of work. For example, in geological exploration, mentoring can last up to 3 years. Some operations are rare and training should take place in practice under the supervision of an experienced technician.

Professional development and training of personnel takes place both within the company on its own and with the involvement of external specialists. "Nobel Oil" cooperates with an oil and gas university, where personnel training is carried out. The internal training system at Nobel Oil is closely related to mentoring, because these are joint programs.

The search and selection of personnel is carried out without the participation of recruitment agencies (although there is such experience), mainly using the channel of job sites. Search through existing employees practically does not work, as the company believes that it is not always possible to trust the recommendations of its employees. And since the assessment of candidates still exists, then there is no need to limit yourself, especially since hh.ru is full of candidates.

\section{Discussion}

The HR outsourcing market is closely connected with labor. The labor force aged 15 and over in December 2019 was 75.9 million people, 72.4 million were classified as employed in economic activity and 3.5 million as unemployed, meeting the ILO criteria (i.e. did not have a job or profitable occupation, were looking for a job and were ready to start it in the surveyed week). The dynamics of the unemployment rate in the Russian Federation is shown in Figure 3.

In general, over the past 5 years, the unemployment rate has been relatively stable at $4.5-5.5 \%$.

An interesting trend is that the level of employment in the leading regions in terms of GRP is higher than in other regions. So, with an average indicator of $59.8 \%$ of the employed in the Russian Federation (as of 2019), the same indicator in the Yamalo-Nenets Autonomous Okrug is $74.5 \%$, in the Khanty-Mansi Autonomous Okrug 69.9\%, in Moscow $67.4 \%$, in St. Petersburg $66.6 \%$.

This trend is partly explained by the specifics of the rotational work method in YAMAO and KhMAO, as well as by internal migrations of the population towards Moscow and St. Petersburg. 


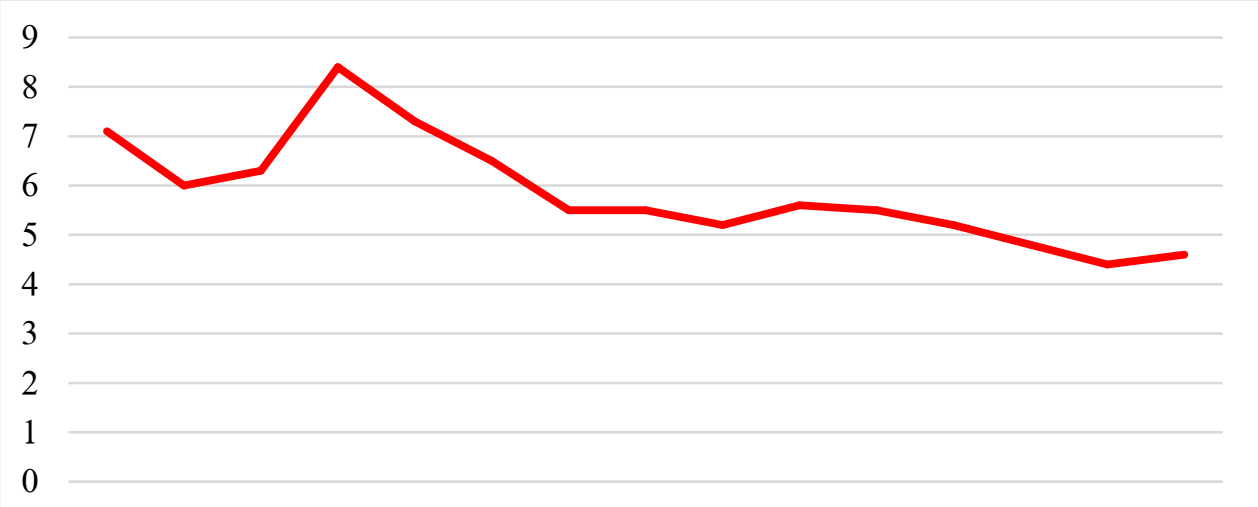

200620072008200920102011201220132014201520162017201820192020

Fig. 3. Unemployment rate in the Russian Federation, \% of the economically active population (according to Rosstat data).

In 2019, the total volume of the Russian market for recruiting, staffing and outsourcing was 79.7 billion rubles (doubled in 6 years from 37.6 billion rubles in 2013). The market for the selection of permanent personnel showed moderate growth (by $7.7 \%$ compared to the previous year). The labor supply market for workers in accordance with Federal Law116 in 2019 grew by $12.2 \%$, and the outsourcing market by $14.7 \%$ (Fig. 4).

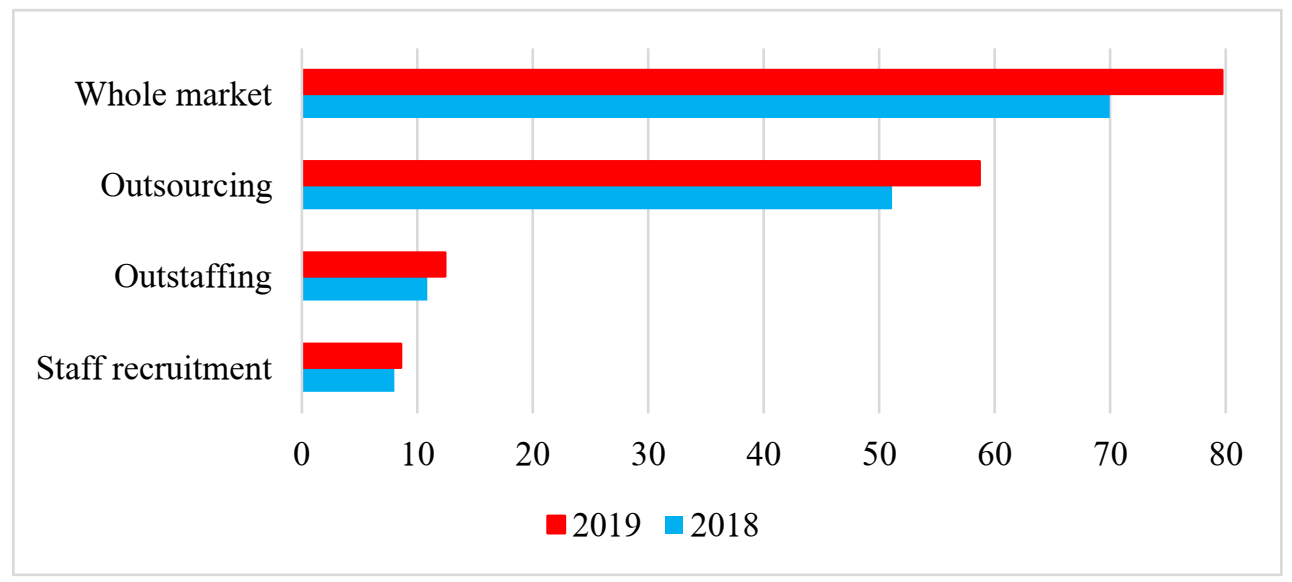

Fig. 4. Turnover of the recruitment, staffing and outsourcing market, billion rubles.

The Russian recruiting market in 2018 showed moderate growth. According to the research, Russian recruiting companies filled in vacancies for a total of 7.993 billion rubles (compared to 7.440 billion rubles in 2017). Most often, companies hired specialists through agencies $-40 \%$, line managers - $35 \%$, initial positions - $13 \%$, and top managers $-12 \%$ [6]. In the study, the vacancies that were transferred to the work of agencies were divided into two types: professional recruitment - vacancies for specialists and managers, and mass recruitment - vacancies of the same type that did not require work experience or special training from applicants. The average cost of a position in mass selection decreased and amounted to 35978 rubles in 2019 (up from RUB 47901 in 2018).

As part of the recruitment service in 2019, companies recruited specialists through agencies $-40 \%$, line managers - $35 \%$, starting positions $-13 \%$, and top managers $-12 \%$. There is a clear shift towards outsourcing the recruitment of highly qualified personnel, with a simultaneous significant reduction in the initial positions of specialists. The tendency 
to transfer complex vacancies to professionals also influenced the average cost of a position - agency fees in professional recruiting increased (273 754 rubles in 2019 compared to 253 197 rubles in 2018). If the growth trend of outsourcing of highly qualified personnel has been observed steadily over the past years, then the decline in the demand for outsourcing of hiring specialists for initial positions occurred quite sharply, almost 2 times, in 2019, even before the start of the pandemic and the subsequent changes in the employment market.

\section{Conclusion}

Staff problems are typical not only for Russian, but also for foreign companies in the Natural resource sector. The problem of a lack of young personnel is becoming critical for this industry. Oil companies are already in panic as they lack new specialists to replace those who are retiring.

The further digitalization of this sector, which will help to replace at least part of the engineering staff, may partly solve the problem of the personnel crisis. As a result, young IT specialists will be able to replace many traditional oil and gas workers.

The training of young personnel for the Natural resource sector is closely related to the popularity of the profession. The failure of the prestige of natural science specialties in the 90 s - 2000s is now affecting the personnel balance of companies. The prestige of the natural science professions was largely restored in the $2010 \mathrm{~s}$, when it became clear that a number of specialties were in demand from foreign employers or were provided with good salaries in Russia. An analysis of the average "passing" score of the USE for budget-funded places in specialized universities, as well as the cost of training in relevant areas has shown that today the areas "Physics", "Oil and Gas Business", "Geology" are outsiders of higher education (the average score is 79.9 , the average cost is 270 thousand rubles) compared, for example, with "Economics" (the average score is 88.8, the average cost - 444.5 thousand rubles). Efforts by oil and gas companies to create special classrooms in schools are successful, but they cover a statistically minor proportion of students. The oil and gas professions have remained attractive only for production regions, where oil and gas companies are the most attractive employers.

In conclusion, it should be noted that there is a natural outflow of experienced employees in the oil and gas industry due to aging, so the task of training and involving young specialists in the industry will only grow. In this regard, personnel outsourcing in terms of search and selection of personnel against the background of the development of digital recruitment tools looks unpromising. The observed general trend of HR outsourcing towards process management and personnel training is relevant in the Natural resource sector even more than in other industries, especially in the area of personnel training. Thus, a certain process of transformation of the education system in this industry is taking place. It requires new models of training young personnel, as well as retraining of existing personnel, probably using lifetime learning technologies.

\section{References}

1. M.V. Voronin, A.I. Shinkevich, Competency 7, 53-54 (2020)

2. Paritet Consult, https://www.paritetk.ru/news/kakih-spetsialistov-chashhe-vsegopriglashayut-v-rossiyu-iz-drugih-stran/

3. S.Y. Vorob'ev, The Fuels and Energy Technology Development Institute (IRTTEK) (2020) https://irttek.ru/research/problemy-podgotovki-kadrov-dlya-neftegazovoyotrasli.html 
4. K.A. Urazova, Scientific Notes PNU 4(8), 488-493 (2017)

5. E. Anoshkina, E. Markovskaya, A. Mottaeva, As. Mottaeva, E3S Web of Conferences 210, 13022 (2020) https://doi.org/10.1051/e3sconf/202021013022

6. M.A. El-Reedy, Field development, The Offshore Pipeline Construction Industry (Butterworth-Heinemann, 2020)

7. Hays. Labor market: expectations 2019 vs reality 2020 (2020) 